\title{
The Role of Trade Unions in the Development of the Aerospace Industry
}

\author{
Volodymyr Tsvykh \\ Doctor of Political Sciences, Professor, \\ Taras Shevchenko National University of Kyiv (Kyiv, Ukraine) \\ E-mail: polit_dep@ukr.net \\ https://orcid.org/0000-0003-3106-7454 \\ Dmytro Nelipa \\ Doctor of Political Sciences, Associate Professor, \\ Taras Shevchenko National University of Kyiv (Kyiv, Ukraine) \\ E-mail: d.v.nelipa@gmail.com \\ https://orcid.org/0000-0002-5363-3990
}

The development of society in the direction of space exploration makes its own adjustments to the development of trade unions. A new system of social partnership is being created in society, in which individualized forms of labor use are dominated. It became possible to establish direct informal contacts between employers and employees. In fact, modern labor relations do not provide for mediation services that have historically been performed by trade unions. However, the activities of trade unions have gone beyond the narrow framework of the previously inherent to them functions of protecting the interests and rights of employees. Trade unions have become a social institution that provides a balance of social and economic interests of employees and employers. In the article, the authors proved that, reflecting the interests of civil society on the transition from planetary to space activities, the unions of the aerospace industry had changed the format of their activities: 1) the educational function became the priority function of trade unions of the aerospace industry, which oriented the work of trade unions towards continuous staff development; 2) the qualified personnel was in need of special working conditions and protection. In order to preserve qualified personnel in the aerospace industry, trade unions with a complex of institutional, infrastructural and legislative measures had to ensure the most favorable working conditions and their protection.

Keywords: trade union, civil society, aerospace industry, space exploration, qualified personnel

Received: February 15, 2019; accepted: March 16, 2019

Philosophy and Cosmology, Volume 23, 2019: 112-120.

https://doi.org/10.29202/phil-cosm/23/10

(C) Tsvykh, Volodymyr, 2019

(C) Nelipa, Dmytro, 2019 


\section{Introduction}

The voluntary association of hired workers, on the basis of their common interests associated with work is commonly understood as trade union. Trade unions are created to improve the living and working conditions of workers and their families. The history and main stages of the development of trade unions are set forth, for example, in the book "Trade Union and Social Studies" [Musson, 2012]. The first trade unions arose up in England and France in the second half of $18^{\text {th }}$ of century. Appearance of trade unions was caused by more wide motion of society in the direction of defending of the interests. The precursors of trade unions were guilds of Middle Ages, freemasonry, secret societies (Oddfellows) and other forms of social organizations.

In the early stages of their development, trade unions existed outside the law and were prosecuted by the state. Only in 1869 the United Kingdom Parliament heard "The Eleventh and Final Report of the Royal Commissioners appointed to Inquire into the Organization and Rules of Trades Unions and Other Associations" (1868-1869). At the end of the investigation, the Royal Commissioners had divergence of their opinion and presented two reports to Parliament: Majority Report and Minority Report. In 1871, “The Trade Union Act 1871" was adopted on the basis of Minority Report, that legalized trade unions in Great Britain. British Parliament established an obvious benefit from trade unions for economic development of the state [Musson, 2012].

The development of trade unions and their influence on the development of industries in each state has its own history. However, Jill Humphrey highlighted the general trend that links the development of the trade union movement with the stages of the formation of civil society. In parallel with the development of civil society, there is a transition of trade unions from the direct protection of the interests and rights of employees to social partnership and further, right up to the industrial democracy and self-government [Humphrey, 2017]. Exactly this way of development was passed by all trade unions in the highly developed democratic states.

The established correlation between the development of trade unions and the stages of the formation of civil society determines the goal of our research. In the article, the authors will reveal the features of the influence of trade unions on the development of society, as well as the role of trade unions in the development of the aerospace industry.

\section{Trade unions as a social institution of civil society}

The term "civil society" is one of the key in modern sociology. Civil society is a system of social institutions that are independent of the state and that are in complex relationships with each other, which are based on individual freedom, political pluralism and democratic sense of justice. Social institutions that form civil society are designed to provide the most favorable conditions for the self-realization of individuals and their associations, realization of private interests and needs. Just the groups of interests, that are determined by the coordinated, concerted and, interacted interests of individual subjects, which self-assemble (in the sense of the Plotin's term [Bazaluk, 2018]) into a holistic subject, or a carrier of group interest, are the driving force of the development of civil society. For this reason, groups of interest are key elements of civil society. They reflect the true diversity, pluralism and degree of self-organization of the interests of citizens, as well as the possibility of their selfrealization in everyday life.

Trade unions arose up as a form of institutionalization of the interests of employees. Their basic function is protection of the economic interests of employees in front of employers. 
Trade unions, as institute of civil society, are based on the voluntarily association of citizens for the most complete individual and collective self-realization, and also protection of the general interests related to work. At present, it is customary to distinguish five types of work: hired, private (work for yourself), civil, social and educational. In highly developed civil societies, trade unions play an essential integrative role, the self-assembly role in every type of work, when it comes to wage workers.

Trade unions as an institution of civil society, regardless of their location and actions, are formed in the following order of the cause-and-effect actions:

1. The system of wage labour generates inevitable contradictions between a hired worker and an employer, as an employer naturally seeks the ways to reduce the production costs, to save, and get more profit, including by reducing the wages of an employee.

2. 2. Meeting the social and economic needs of employees, ensuring and protecting their rights and interests, is effectively ensured only as a result of joint collective action, and not one by one. For this reason, hired workers unite in social unions, trade unions voluntarily.

3. 3. Trade union management is aimed at uniting employees in order to protect their legitimate rights and interests. Trade union is created to protect economic freedom and independence, and as a result, social freedom.

H. Musson marked that trade unions, as institute of civil society, had been formed historically on the basis of interests in the sector of economy [Musson, 2012]. For a long time, the main activity of the trade unions was the organization and the most profitable sale of labor. The effectiveness of trade unions was determined by the degree of achievement of these goals. Trade union management was aimed at providing employment; decent wages; guaranteed its payment; the creation of working conditions; the development of democracy in the workplace; etc. The degree of development of trade unions in society is determined on the basis of the concept of "union density." This concept establishes the percentage of the number of workers in a trade union to the total number of workers involved in this field of activity.

The degree of development of trade unions in society is determined on the basis of the concept of "union density." This concept establishes a percentage of the number of employees in a trade union to the total number of workers involved in this field of activity. According to Organisation for Economic Co-operation and Development (OECD) the greatest density of trade unions is represented in the Nordic countries. For example, the density of trade unions in Germany in 2016 was 67, 2\%; in Finland - 64, 6\%; in Iceland - 90.4\%; in Norway 52.5\%; in Sweden - 67\% [Organisation, 2019]. In North America due to Trump's anti-union policies trade union activity has declined significantly. In the USA, according to Timothy Noah, only 42 percent of self-identified Republicans approved of labor unions (against 81 percent of Democrats) [Noah, 2017].

\section{Features of the influence of trade unions on the development of society}

The development of civil society and its institutions expanded the influence of trade unions. In addition to the economic sphere, trade unions began to exert influence in other spheres of activity: in political and social struggle. In the second half of the $20^{\text {th }}$ century, individual trade unions began to unite into larger associations - Federations. Trade union management reached a new level of excellence: from sectoral to the level of national importance. New organizational power of the trade union federation was directed to the development of social 
policy, to consolidation of favorable working conditions in the legislation. The political importance of trade unions increased, especially in presidential and parliamentary election campaigns. Trade Union leaders gained political power and began to build complex relations with the state, political parties and local self-government bodies. The influence of trade unions acquired new forms: lobbying, cooperation with political parties, interaction with the authorities.

Numerous examples show the influence of trade unions on the development of society. For example, the impact of National Union of Mineworkers (NUM) in Great Britain in the second half of the twentieth century. In 1974, the activity of the National Union of Mineworkers (NUM) led to the resignation of the conservative British government headed by Edward Heath, and in 1984-85, the Union challenged the government of Margaret Thatcher [Musson, 2012]. The second example, now in the USA there is hard opposition between trade unions and the government of republicans. Timothy Noah writes, that just a year after Donald Trump had came to power, the following anti-union actions were taken [Noah, 2017]:

1. The Republican-majority Supreme Court will this year likely outlaw "fair share" fees from union non-members, dealing a financial blow from which public-employee unions might never recover.

2. The National Labor Relations Board, which recently acquired its first Republican quorum in 10 years, is poised to roll back a passel of pro-union decisions from the Obama years.

3. The Labor Department is watering down a regulation that would have extended overtime coverage to more than 4 million new people.

4. The Occupational Safety and Health Administration is weakening or postponing a variety of rules to protect workers' exposure to hazardous chemicals like silica and beryllium.

5. The Treasury and Congress are preparing a tax bill that may encourage the offshoring of jobs through reduced taxes on overseas corporate income and discourage construction by capping the mortgage interest deduction at $\$ 500,000$, both serious blows to union workers.

The impact of trade unions on the development of society is determined by the four functions that are naturally inherent in trade unions as a social institution of civil society:

1. The socio-economic function, which provides for the increase of socio-economic status of employees by improving their work and life by optimizing the production process, developing the social infrastructure and perfection of the remuneration system.

2. The political and legal function, which provides for the interests of employees through the provision of legal services, the achievement of more democratic legislation, the right to influence on decision-making in public policy and in industry.

3. The educational and cultural function, which orients the management of trade unions to improvement of the educational and cultural level of employees by creating for them an accessible system of education and self-education, obtaining qualification and retraining, cultural recreation and development, as well as satisfaction personal inclinations and needs.

4. The social and civil function, which directs the influence of trade unions on assisting in the formation and development of a variety of self-governing civil associations; joint objectives and problems solving; active participation in public affairs. 
The features of influence of trade unions on the development of society can be divided into two groups. The first group includes the following areas:

1. Reduction of employee turnover in the production.

2. Ensuring the right of a voice to workers, worthy compensation and provision of pensions.

3. Expansion of informal communication and voluntary mutual assistance in the workplace, which led to a significant reduction of social tension in the relationship between employees, as well as between employees and employers.

4. Improvement of the morale and motivation of employees; ensuring their protection from dismissal and discrimination.

5. Improvement of working conditions. Complaints of workers began to get a response in administration. 6 . The trade unions made the administration comply with production standards, increase product turnover and improve accountability.

6. The contracts that were concluded between the employee and the employer through the mediation of the trade unions became an important channel of communication between the employees and the administration.

The second group includes the functional orientation on:

1. The expansion of the rights and freedoms of a man and citizen, which is achieved through the activity and struggle of trade unions. This is the basic functional orientation of the influence of trade unions on the development of civil society.

2. Statement and improvement of the social partnership system, which helps to stabilize and consolidate civil society.

3. The development of self-government processes, which are the necessary requirements for the further dynamic development of civil society as a whole.

Achieving the maximum influence of trade unions on the development of society is possible only if the organization of trade unions is based on four key characteristics: voluntariness, independence, democracy and unconditional protection of the economic and social interests of employees.

\section{The role of trade unions in the development of the aerospace industry}

As we have shown above, the trade unions, as a social institution, reflect the interests of civil society. In turn, as it has been revealed in the book reviews "The Idea of the World: a Multi-Disciplinary Argument for the Mental Nature of Reality", the interests of society are determined by the Mental Nature of Reality, in which Man is a reflection of the evolution of the Universe [Bazaluk, 2018]. That is why the development of social and economic relations has an obvious focus on space exploration. It is just for this reason the trade unions, as an institution of civil society that has been formed historically in the economic sector, began to ensure a balance of the social and economic interests of employees and employers in the space industry. This tendency is reflected even in the names of trade unions that have had more than a centenary history. For example, in the title "The International Association of Machinists and Aerospace Workers" (IAM). This Trade Union brings together nearly 600,000 active and retired members in North America, who work at such enterprises as Boeing, Lockheed Martin, United Airlines, Harley-Davidson, etc. The trade union has existed for over 130 years and its history fully reflects the transition of society from planetary activities to aerospace ones [International, 2019]. 
The aerospace industry has one important feature that has a direct impact on the development of trade unions. The aerospace industry is based on the technological basis for the designation of which the proper term has not been established yet. In different states specialists use different terms: "Industry 4.0," "Industry of the future," "Digitalisation," etc. However, all these terms have a general meaning: the technological basis is highly efficient, future oriented network infrastructure, which has to process the huge amount of data fast and effective. Accordingly, the trade unions of the aerospace industry unite the highly qualified personnel that also needs continuous increase in the qualification.

The current challenges, tasks, and peculiarities of the influence of the trade unions of the aerospace industry, we will consider, using as example, three workshops that took place in 20162017 in Spain, France and Poland. Based on the results of intensive communication between the leaders of the European aerospace industry, the documentation "Demographic change, personnel work and skilled employment in the European aerospace industry. Information, facts and practices for trade unions and works councils" was compiled and published. This documentation provides information on the demographic challenges facing the European aerospace industry and the activities of trade unions under the CHANGE project for sustainable personnel work, for healthy, age appropriate and good working conditions and for securing skilled workforce [Demographic, 2017].

The First workshop took place from the $21^{\text {st }}$ to the $23^{\text {rd }}$ September 2016 in Madrid, Spain [CHANGE, 2016]. For the first time, representatives of the largest trade unions of the aerospace industry from eight European countries gathered at a round table to discuss the key issues facing them. The participants of that meeting proved, using the example of Spain, that against the background of job cuts in the aerospace industry, a strategy of wage dumping, narrowing of the rights and spheres of activity of trade unions through political and legal measures, the opposite tendency had been observed. There was an increase in the European trade union movement. The demand for qualified personnel increases with each decade and only trade unions can satisfy it, using their capabilities and influence. The workshop participants came to the conclusion that, at present, trade unions of aerospace industry should focus on two of the most urgent topics: "Ageing in health and competence" and "Promoting, acquiring and holding qualified personnel." The latter topic, in accordance with the unanimous opinion, is a priority one [CHANGE, 2016]. The main result of the $1^{\text {st }}$ workshop was the preparation of "action plans" according to a specific time-table, with tangible "projects" being defined for certain country-specific or company-related activities [CHANGE, 2016]. "Action plans" pursued the main goal - the preservation and retention of the qualified workforce in the aerospace industry.

The $2^{\text {nd }}$ workshop took place from the $15^{\text {th }}$ to the $17^{\text {th }}$ of February 2017 in Toulouse, France. The Summit was attended by 21 representatives of trade unions from the European aerospace industry [CHANGE, 2017]. If the $1^{\text {st }}$ workshop in Madrid was more exploratory in nature and led to the preparation of "action plans", then the $2^{\text {nd }}$ workshop in Toulouse was constructive. At the $2^{\text {nd }}$ workshop, in essence, the role of trade unions in the space industry was formulated, as well as the main directions of their activities were disclosed. Let us note the following significant, from our point of view, events of the $2^{\text {nd }}$ workshop in Toulouse:

Firstly, Bernard Tagneres (General Secretary of CFDT for the Airbus Group) revealed the social structure of the Airbus Group, which is typical for the trade unions of the aerospace industry of Europe in principle. From his statistics it follows: there are currently 53 factories in France with 2.200 production sites that work as suppliers or service providers for the aerospace branch. In general, there is no data on the Airbus Group, but for example, in Toulouse: in the factories with more than 500 workers, $26 \%$ are engineers. $90 \%$ of the workers are younger than 
55 years and $60 \%$ are under 45 years old. The proportion of women is low [CHANGE, 2017].

Secondly, Wolfgang Anlauft, representing ffw $\mathrm{GmbH}$, formulated 4 categories for the work political work arrangement [CHANGE, 2017]:

1. Safety - which group would be pushed over the existence edge by which developments and processes?

2. Qualification - which qualification would be connected to which activity - more important than organisational charts would be the professional development paths?

3. Work arrangement - how to arrange workplaces, so that they would be interesting, motivating, age-appropriate and would promote learning for all employee groups?

4. Social support - qualification should secure a person's future, but what happens when social groups do not belong anymore to that future?

These four categories specify the strategy for development of the trade unions of the aerospace industry, as well as the peculiarities of their influence on the political, social and economic development of society.

Thirdly, Franck Uhlig, representing FGMM CFDT, one of the largest trade union organizations in France, proposed eight key questions that would allow to evaluate and predict the work of trade unions of the aerospace industry at the implementation of Industry 4.0-Models [CHANGE, 2017]:

1. How can innovation, automatisation and rationalisation be arranged in social and employees' fair matter?

2. Which working places will be in danger because of the usage of digital technologies and infrastructures and which new working places can be created?

3. How can the loss of working places be compensated with new products, intelligent systems, services and business models and where can be created new jobs?

4. How will be arranged the working processes, e.g. the relation between man and technic - are there only low qualified profiles left for the man or can he use more action field and more responsibilities with a better qualification?

5. How can the employees keep their qualification constantly up-to-date regarding the new requirements?

6. If working time and workspace can become more and more flexible — does this give more individual decision-making freedom and chances for work-life-balance or does it threat the borders between work, always growing performance pressure and more physical and psychological load?

7. Will the workforce become a mix from permanently employed and external workforce to the externalisation of small tasks to "digital day labourers" (Crowd working)?

8. How should joint decision-making in the companies and engagement of employees be further developed, in order to co-create the working world in a positive way?

The participants of the $2^{\text {nd }}$ workshop came to the unanimous opinion that "Occupational models need social models!" the development of enterprises needs social support [CHANGE, 2017]. In this regard, it is necessary to learn from the experience of France and the Netherlands, where there are qualification funds. The $2^{\text {nd }}$ workshop participants also noted the opportunities of the UK Aerospace Training Programme. It has developed a training package for every single machine and every work step [CHANGE, 2017].

The $3^{\text {d }}$ final project meeting took place from $11^{\text {th }}$ to $13^{\text {th }}$ July, 2017 in Rzeszów, Poland. The meeting was attended by the representatives of 11 trade unions of eight EU countries. They 
represented the multinational companies such as Airbus, Safran, Rolls Royce, Saab, GKN, Telespazio [European, 2017]. The result of the $3^{\mathrm{d}}$ final meeting was the specific vision of the future of trade unions in the development of the aerospace industry.

In general, analyzing the role of trade unions in the development of the aerospace industry, we can make two main conclusions:

1. The educational function has become a priority function of the trade unions of the aerospace industry, which orients the work of the trade unions towards continuous staff development. For these purposes, trade unions need to create the appropriate infrastructure and develop affordable education and self-training systems.

2. The qualified personnel is in need of special working conditions and protection. In order to retain qualified personnel in the aerospace industry, trade unions should ensure the most favorable social package conditions. For example, members International Association of Machinists and Aerospace Workers (IAM) have the following advantages: a) Earn wages, on average, 26 percent higher than non-union workers; б) 89 percent of union workers participate in a defined benefit program while 46 percent of nonunion workers participate in a defined benefit plan; в) Are more likely to have employer-provided health insurance benefits; г) Have greater access to apprenticeships and training opportunities [International, 2019].

\section{Conclusions}

The development of society in the direction of space exploration makes its own adjustments to the development of trade unions. Anew system of social partnership is being created in society, in which individualized forms of labor are dominated. It became possible to establish direct informal contacts between employers and employees. In fact, the modern labor relations do not provide for mediation services that have been performed historically by trade unions. However, the activities of trade unions have gone beyond the narrow framework of the previously inherent functions of protecting the interests and rights of employees. Trade unions have become a social institution that provides a balance of social and economic interests of employees and employers. The trade unions began to carry out a much larger complex of institutional, infrastructural, and legislative measures, which provides for the establishment of the appropriate subsystems: institutional and infrastructural, informational and communication, and normative-regulatory. Currently, the activities of trade unions include the following directions:

1. Joint development, adoption and implementation of policies in the field of socioeconomic and labor relations, which is based on a balance of interests of employees, employers and the interests of society.

2. Joining forces in the name of joint actions, the purpose of which is improvement of social and economic protection of employees, employers and society.

3. Prevention and joint solution of negative phenomena and conflicts in the social and labor sphere.

4. Regulation of wages in the public and private sectors of the economy.

5. Labor protection and creation of conditions for labor safety.

6. The development of the labor market and employment of the population.

7. Achievement of optimal coordination of the economic and social interests of the parties of the social partnership.

8. Ensuring sustainable development of production, improving the quality of life of employees through consultations, negotiations and agreements based on the labor and civil law. 
9. Creation of conditions and infrastructure for continuous professional development of employees.

Reflecting the interests of civil society in the transition from planetary to space activities, trade unions of the aerospace industry have changed the format of their activities:

1. The educational function has become a priority function of the trade unions of the aerospace industry, which orients the work of the trade unions towards continuous staff development. For these purposes, trade unions need to create the appropriate infrastructure and develop affordable education and self-training systems.

2. The qualified personnel is in need of special working conditions and protection. In order to retain qualified personnel in the aerospace industry, trade unions should provide for the most favorable working conditions and labour protection by means of complex of institutional, infrastructural, and regulatory measures.

\section{[L] References}

Bazaluk, Oleg. The Feature Transformations of the Basic Meanings of Greek Paideia in the Educational Theories in the Middle Ages. Schole, Vol. 12.1, 2018: 243-258. https://doi. org/10.21267/AQUILO.2018.12.10428.

Bazaluk, Oleg. The Ontology of Existence: the Next Paradigm. A Review of the Book "The Idea of the World: a Multi-Disciplinary Argument for the Mental Nature of Reality" by Bernardo Kastrup. Anthropological Measurements of Philosophical Research. 14, 2018: 180-183. https://doi.org/10.15802/ampr.v0i14.151745

Bazaluk, Oleg, Vasyl Fatkhutdinov, and Denys Svyrydenko. The Potential of Systematization of the Theories of Education for Solving of Contradictions of Ukrainian Higher Education Development. Studia Warmińskie, Vol. 55, 2018: 63-79. https://doi. org/10.31648/sw.3062

CHANGE - Trade Unions' Cooperation in the Aerospace Industry. September 2016. http:// www.air-change.eu/fileadmin/introduction/downloads/Konferenzen/Madrid/Dateien/ Mehr/Bericht-Madrid-EN.pdf

CHANGE - Trade Unions' Cooperation in the Aerospace Industry. February 2017. http:// www.air-change.eu/fileadmin/introduction/downloads/Konferenzen/Toulouse/ Dateien/EN_Bericht_Toulouse.pdf

Demographic change, personnel work and skilled employment in the European aerospace industry. Information, facts and practices for trade unions and works councils. October 2017. http://www.air-change.eu/fileadmin/introduction/downloads/Report/ChangeReport_2017.pdf

European project meeting, Rzeszów (Poland), 2017. http://www.air-change.eu/index. php?id=89\&L=3

Humphrey, Jill. Towards a Politics of the Rainbow: Self-Organization in the Trade Union Movement. Routledge, 2017. https://doi.org/10.4324/9781315188744

International Association of Machinists and Aerospace Workers (IAM), 2019. https://www. goiam.org/

Musson, H.E. Trade Union and Social Studies. Routledge, 2012.

Noah, Timothy. Does Labor Have a Death Wish? POLITICO, November 07, 2017. https://www. politico.com/magazine/story/2017/11/07/labor-movement-trump-betrayal-215796

Organisation for Economic Co-operation and Development (OECD), 2019. http://www.oecd. org/ 